\title{
Verifikasi Metode Pengujian Sulfat Dalam Air dan Air Limbah Sesuai SNI 6989.20 : 2009
}

\author{
Methods Verification of Sulfat Analysis in Water and Wastewater
}

Based On SNI 6989.20:2009

\author{
Ardhaningtyas Riza Utami \\ Kementerian Perindustrian \\ Balai Riset Dan Standardisasi Industri Surabaya \\ Surabaya, Indonesia \\ riza2308@gmail.com
}

\begin{abstract}
Abstrak - Verifikasi metode pengujian sulfat dalam air dan air limbah secara turbidimetri yang mengacu pada SNI 6989.20 : 2009 telah dilakukan. Didapatkan Limit of Quantity $(\mathrm{LOQ})=$ $1,921 \mathrm{mg} / \mathrm{L}$, Method Detection Limit $(\mathrm{MDL})=0.6038 \mathrm{mg} / \mathrm{L}$. Kurva kalibrasi untuk konsentrasi $>5 \mathrm{mg} / \mathrm{L}$ dan konsentrasi $<5$ $\mathrm{mg} / \mathrm{L}$ mempunyai derajat linearitas $(r)=0.997$ dan 0.998 . RSD presisi contoh $=3.187 \%$, sedangkan RSD reproducibility contoh $=2.60 \%$. Hasil verifikasi metode tersebut memenuhi syarat keberterimaan, sehingga metode tersebut dapat diterapkan di laboratorium.
\end{abstract}

Kata Kunci - verifikasi, sulfat, Limit of Quantity (LOQ), Methods Limit Detection (MDL), Kurva Kalibrasi, derajat linearitas, RSD, presisi, Reproducibility,

Abstract - Verification testing methods sulfate in water and wastewater turbidimetry that refer to SNI 6989.20: 2009 has been done. Obtained Limit of Quantity $(L O Q)=1.921 \mathrm{mg} / \mathrm{L}$, Method Detection Limit $(M D L)=0.6038 \mathrm{mg} / \mathrm{L}$. The calibration curves for concentration $>5 \mathrm{mg} / \mathrm{L}$ and the concentration of $<5 \mathrm{mg} / \mathrm{L}$ has a degree of linearity $(r)=0997$ and 0998. $R S D$ precision sample $=$ $3,187 \%$, while the sample reproducibility $R S D=2.60 \%$. Results of verification methods are qualified acceptance, so the method can be applied in the laboratory.

Keywords - verification, sulfate, Limit of Quantity (LOQ), Methods Limit Detection (MDL), calibration curve, degree of linearity, RSD, precision, Reproducibility.

\section{PENDAHULUAN}

Laboratorium lingkungan melaksanakan fungsi sebagai laboratorium penguji parameter yang terkait dengan baku mutu lingkungan. Kegiatan pengujian tersebut identik dengan kegiatan pengendalian mutu. Seperti halnya dalam menilai kesesuaian spesifikasi uji atau objek uji, Analis kimia dituntut untuk mampu menghasilkan data yang objektif dengan nilai akurasi dan presisi yang sesuai dengan persyaratan dalam metode yang diacu. Mengingat pentingnya peran laboratorium lingkungan, khususnya terkait kemampuan laboratorium dalam mempertahankan konsistensi serta mengontrol kinerjanya, tentunya presisi serta akurasi data menjadi pertimbangan utama dalam penentuan kesesuaian spesifikasi objek yang diuji. Sehingga laboratorium harus mampu memberikan jaminan mutu hasil pengujian kepada pelanggannya melalui pemantauan, pemeliharaan dan pengendalian kualitas kinerja laboratorium tersebut.

Pengujian sulfat pada air dan air limbah secara turbidimetri yang mengacu pada SNI 6989.20:2009 mempunyai kisaran kadar $1 \mathrm{mg} / \mathrm{L}$ sampai dengan $40 \mathrm{mg} / \mathrm{L}$ dengan tebal kuvet 2,5-10 $\mathrm{mm}$ dan kisaran $5 \mathrm{mg} / \mathrm{L}$ sampai dengan $70 \mathrm{mg} / \mathrm{L}$ dengan tebal kuvet $1 \mathrm{~mm}$. Tebal kuvet mempunyai pengaruh dalam pengujian karena pengujian ini berdasarkan pada kekeruhan sampel. Prinsip dari pengujian ini adalah ion sulfat dalam suasana asam bereaksi dengan Barium Clorida $\left(\mathrm{BaCl}_{2}\right)$ membentuk kristal barium sulfat $\left(\mathrm{BaSO}_{4}\right)$ yang serba sama [3]. Sinar yang diserap oleh suspensi barium sulfat diukur dengan fotometer dan kadar sulfat dihitung secara perbandingan pembacaan dengan kurva kalibrasi.

Verifikasi merupakan suatu uji kinerja metode standar. Metode standar adalah metode yang dikembangkan dan ditetapkan oleh suatu organisasi atau badan standardisasi nasional suatu Negara. Metode standar ini diterima secara luas, misalnya : ISO, ASTM, BSN, SNI dan lain sebagainya. Verifikasi ini dilakukan terhadap suatu metode standar sebelum diterapkan di laboratorium. Verifikasi sebuah metode bertujuan untuk membuktikan bahwa laboratorium yang bersangkutan mampu melakukan pengujian dengan metode tersebut dengan hasil yang valid. Disamping itu juga bertujuan untuk membuktikan bahwa laboratorium memiliki data kinerja. Hal ini dikarenakan laboratorium yang berbeda memiliki kondisi dan kompetensi personil serta kemampuan peralatan yang berbeda. Sehingga kinerja antara satu laboratorium dengan laboratorium lainnya berbeda.

Di dalam verifikasi metode, kinerja yang akan diuji adalah keselektifan, seperti uji akurasi (ketepatan) dan presisi (kecermatan). Suatu metode yang presisi belum menjadi jaminan bahwa metode tersebut dikatakan akurat. Begitu juga 
sebaliknya, suatu metode yang tepat (akurat) belum tentu presisi.

Akurasi diartikan sebagai kedekatan hasil analisa terhadap nilai yang sebenarnya. Presisi diartikan sebagai kedekatan antara sekumpulan hasil analisa. Sedangkan reliabilitas data adalah gabungan antara presisi dan akurasi. Dengan kata lain, akurasi bertujuan untuk mendapatkan suatu nilai yang benar. Presisi bertujuan untuk mendapatkan nilai yang sama. Sedangkan reliabilitas data adalah untuk mendapatkan nilai yang benar dan sama.

Reliabilitas data (keandalan suatu data) merupakan syarat mutlak yang harus dimiliki oleh suatu laboratorium analisa. Suatu laboratorium yang berkualitas harus dapat mengeluarkan data-data yang andal dan dapat dipercaya (memiliki akurasi dan presisi tinggi).

Validasi adalah konfirmasi suatu metode melalui pengujian dan pengadaan bukti bahwa syarat-syarat tertentu dari suatu metode telah dipenuhi. Validasi perlu dilakukan oleh laboratorium terhadap : metode non standar, metode yang dikembangkan sendiri, metode standar yang digunakan diluar lingkup yang dimaksud, metode standar yang dimodifikasi dan metode standar untuk menegaskan dan mengkonfirmasikan bahwa metode tersebut sesuai dengan penggunaaannya. Validasi metode melibatkan keseluruhan prosedur analisis. Mulai dari pengambilan sampel, preparasi sampel, analisis dan evaluasi data dan pelaporan hasil. Halhal yang terkait sebelum melakukan validasi metode antara lain : instrument, bahan / reagen, analis dan dokumen. Dalam melakukan validasi metode parameter yang diuji harus meliputi: akurasi, presisi, limit of quantity (LOQ) / Methods Detection Limit (MDL), working range, linear range.

\section{Akurasi}

Akurasi atau kecermatan adalah ukuran yang menunjukan derajat kedekatan hasil analis dengan kadar analit yang sebenarnya. Terkadang masalah dalam menentukan akurasi adalah ketidaktahuan terhadap nilai yang sebenarnya. Dalam beberapa tipe sampel kita dapat menggunakan sampel yang telah diketahui nilainya dan mengecek metode pengukuran yang kita gunakan untuk menganalisis sampel itu, sehingga kita mengetahui akurasi dari prosedur yang diujikan. Metode ini disebut dengan CRM (Certified Reference Method). Pendekatan lain adalah dengan membandingkan hasilnya dengan hasil yang dilakukan oleh laboratorium lain atau dengan menggunakan metode referen. Akurasi juga dapat diketahui dengan melakukan uji perolehan kembali (recovery). Hasil uji akurasi dapat dinyatakan sebagai persen perolehan kembali (recovery) analit yang ditambahkan pada sampel. Rentang nilai penerimaan kecermatan suatu metode akan bervariasi sesuai kebutuhannya. Adapun AOAC [1] menetapkannya seperti dalam Tabel 1 .

TABEL I. PERSENTASE RECOVERY YANG DAPAT DITERIMA SESUAI DENGAN KONSENTRASI ANALIT

\begin{tabular}{|c|c|c|}
\hline$(\boldsymbol{\%})$ analit & Unit & $\begin{array}{c}\text { Rata-rata recovery } \\
(\boldsymbol{\%})\end{array}$ \\
\hline $10^{2}$ & $100 \%$ & $98-102$ \\
\hline
\end{tabular}

\begin{tabular}{|c|c|c|}
\hline 10 & $10 \%$ & 95 \\
\hline 1 & $1 \%$ & $97-103$ \\
\hline $10^{-1}$ & $0.10 \%$ & $95-105$ \\
\hline $10^{-2}$ & $100 \mathrm{ppm}$ & $90-107$ \\
\hline $10^{-3}$ & $10 \mathrm{ppm}$ & $80-110$ \\
\hline $10^{-4}$ & 1 & $80-110$ \\
\hline $10^{-5}$ & $100 \mathrm{ppb}$ & $80-110$ \\
\hline $10^{-6}$ & $10 \mathrm{ppb}$ & $60-115$ \\
\hline $10^{-7}$ & $1 \mathrm{ppb}$ & $40-120$ \\
\hline
\end{tabular}

\section{Presisi}

Presisi adalah ukuran yang menunjukkan derajat kesesuaian hasil uji individual. diukur melalui penyebaran hasil individual dari rata-rata, jika prosedur diterapkan secara berulang pada sampel-sampel yang diambil dari campuran yang homogen [2]. Presisi dapat dibagi dalam dua kategori yaitu keterulangan (repeatability) dan ketertiruan (reproducibility). Repeatability adalah nilai presisi yang diperoleh jika seluruh pengukuran dihasilkan oleh satu orang analis dalam satu periode tertentu, menggunakan contoh yang sama, pereaksi dan peralatan yang sama dalam laboratorium yang sama.

Ketertiruan (Reproducibility) adalah nilai presisi yang dihasilkan pada kondisi yang berbeda. Misalnya analis yang berbeda pada laboratorium yang sama atau periode dan laboratorium yang berbeda dengan analis yang sama. Karena ketertiruan dapat memperbanyak sumber variasi. Ketertiruan dari analisis tidak akan lebih baik hasilnya dari nilai keterulangan.

\section{Limit of Quantitation (LOQ) dan Methods Detection Limit (MDL)}

MDL merupakan batas deteksi metode yang bisa diuji pada konsentrasi paling rendah. Limit of Quantity (LOQ) merupakan konsentrasi terendah dari analit yang dapat ditentukan dengan presisi dan akurasi yang dapat diterima. Limit deteksi (LOD) adalah konsentrasi terendah yang masih dapat terdeteksi oleh suatu alat [5].

\section{Working range}

Working range merupakan rentang kerja yang dibuat dan disesuaikan dengan kisaran contoh yang akan dianalisa. Mulai batas terendah sampai batas tertinggi. Rentang kerja dibuat dari sederet larutan standard dengan konsentrasi terendah sampai tertinggi (sesuai dengan kisarab contoh). Deret standard tersebut kemudian dibaca absorbansinya dan dibuat kurva kalibrasi, dimana sumbu $\mathrm{Y}$ adalah absorbansi dan sumbu $\mathrm{X}$ adalah konsentrasi. 


\section{Linear Range}

Linear range merupakan rentang linear dalam rentang kerja. Linearitas metode analisis menunjukkan kemampuan suatu metode untuk memperoleh hasil uji yang baik. Linearitas dapat diuji secara informal dengan membuat plot residual yang dihasilkan oleh regresi linier pada respon konsentrasi dalam satu seri kalibrasi [6]. Sebagai parameter adanya hubungan linier digunakan koefisien korelasi $r$ pada analisis regresi linier $\mathrm{Y}=\mathrm{aX}+\mathrm{b}$. Hubungan linier yang ideal dicapai jika nilai $\mathrm{a}=0$ dan $\mathrm{r}=+1$ atau -1 bergantung pada arah garis. Sedangkan $\mathrm{b}$ menunjukan kepekaan analisis terutama instrumen yang digunakan. Nilai koefisien korelasi yang memenuhi persyaratan adalah sebesar $\geq 0,97$ (SNI) atau $\geq$ $0,9980($ AOAC)

\section{Sensitivitas / kepekaan}

Sensitifitas merupakan kemampuan untuk mengukur analit dengan akurat tanpa adanya gangguan dari komponen matriks dalam sampel.

\section{METODOLOGI}

A. Alat dan Bahan :

Metode pengujian sulfat dalam penelitian ini mengacu pada SNI 6989.20 : 2009. Alat dan bahan yang diperlukan antara lain :

- $\quad$ Spektrofotometer pada panjang gelombang $420 \mathrm{~nm}$

- $\quad$ Bekker glass $250 \mathrm{ml}$

- Pipet volumetric

- Magnetic stirrer

- Stopwatch

- $\quad$ Neraca analitik ketelitian 0,1 mg

Bahan yang diperlukan :

- Air bebas mineral

- $\quad$ Barium klorida $(\mathrm{BaCl} 2)$

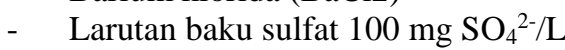

- Larutan buffer A

- $\quad$ Larutan buffer B

\section{B. Metodologi}

\section{Working range dan linear range}

Membuat deret standard dari larutan baku sulfat 100 $\mathrm{mg} / \mathrm{l}$. Working range dibuat dalam 2 range kerja, yaitu untuk konsentrasi $<5 \mathrm{mg} / \mathrm{L}$ dan konsentrasi di atas $5 \mathrm{mg} / \mathrm{L}$. Larutan buffer yang ditambahkan untuk range konsetrasi $<5 \mathrm{mg} / \mathrm{L}$ adalah larutan buffer B, sedangkan untuk sampel dengan konsentrasi $>5 \mathrm{mg} / \mathrm{L}$ ditambahkan larutan buffer A [3]. Deret standard tersebut dibaca absorbansinya dengan menggunakan spektrofotometer pada panjang gelombang $420 \mathrm{~nm}$. Berikut ini adalah working range untuk konsentrasi $<5 \mathrm{mg} / \mathrm{L}$ :

\section{Presisi (Repeatability dan Reproducibility)}

Menyiapkan contoh yang sama dan homogen kemudian diuji minimal sebanyak 7 kali. Pengujian repeatability dilakukan oleh satu orang analis, sedangkan untuk pengujian
Reproducibility dilakukan oleh dua orang analis. Reapitabilitas diukur dengan menghitung Relative Standard Deviation atau simpangan baku relatif (RSD) dari beberapa ulangan contoh yang dilakukan. Dari nilai simpangan baku tersebut dapat dihitung nilai koefisien variannya $(\mathrm{CV})$. Nilai $\mathrm{CV}$ yang diperoleh dari ulangan pengujian contoh (RSD) dibandingkan dengan CV Horwitz. Perhitungan CV (RSD) contoh adalah sebagai berikut :

$$
(R S D)_{\text {contoh }}=\frac{S D}{X r} \times 100
$$

Dimana :

$\mathrm{SD}=$ Standard Deviasi konsentrasi contoh yang dihasilkan dari ulangan pengujian (minimal 7 ulangan)

$\mathrm{Xr}=$ Rata-rata konsetrasi ulangan pengujian

Sedangkan perhitungan CV horwitz adalah sebagai berikut :

$$
\mathrm{CV}_{\text {Horwits }}=2^{1-0,5 \log \mathrm{C}}
$$

Dimana :

$\mathrm{C}=$ konsentrasi rata-rata dari 7 kali pembacaan

Syarat keberterimaannya adalah RSD yang terhitung harus kurang dari $1 / 2$ dari nilai CV Horwits :

$$
\mathrm{RSD}_{\text {contoh }}<1 / 2 \mathrm{CV} \text { horwitz }
$$

Reproducibility diukur dengan menghitung Relative Standard Deviation (RSD) dan CV horwitz dari beberapa ulangan contoh yang dilakukan dengan kondisi yang berbeda. Syarat keberterimaan untuk reproducibility adalah RSD yang terhitung dari ulangan contoh harus kurang dari $2 / 3$ dari nilai CV Horwits [4]

$$
\mathrm{RSD}_{\text {contoh }}<2 / 3 \mathrm{CV}_{\text {horwitz }}
$$

\section{Akurasi}

Menyiapkan contoh dan larutan standard yang telah diketahui konsentrasinya. Sampel yang digunakan untuk pengujian akurasi ini adalah sampel air permukaan, sedangkan konsentrasi standard yang ditambahkan ke dalam sampel tergantung dari konsentrasi sampel.

$\%$ Recovery penambahan standar yang telah diketahui jumlah dan kadarnya ke dalam sampel (spiking) dapat dihitung sebagai berikut;

$$
\% R=\frac{C_{2}-C_{1}}{S} \times 100
$$

\footnotetext{
$\mathrm{R}=$ Perolehan kembali (Recovery)

$\mathrm{S}=$ Kadar analit yang ditambahkan pada sampel

$\mathrm{C}_{1}=$ Konsentrasi sampel

$\mathrm{C}_{2}=$ Konsentrasi campuran sampel dan analit
} 


\section{Limit of Quantitation (LOQ) dan Methods Detection Limit (MDL)}

Limit of Quantity (LOQ) ditentukan dengan menggunakan sampel yang mempunyai kadar paling kecil yang masih bisa terbaca dengan menggunakan metode yang kita gunakan. Pengukuran dilakukan minimal tujuh kali dengan menggunakan sampel yang ditambah spike dengan konsentrasi terkecil. Rata-rata recovery yang didapatkan dari penambahan spike tersebut harus berada pada range $85 \%$ $115 \%$.

Besar limit deteksi (LOD) dinyatakan dengan nilai rata-rata sampel $+3 \mathrm{SD}$. Dimana SD adalah standar deviasi (simpangan baku) dari sampel. Sedangkan besarnya Limit of Quantity (LOQ) biasanya dinnyatakan dengan nilai rata-rata sampel +10 SD. Cara lain untuk menentukan batas deteksi dan kuantitasi adalah melalui penentuan rasio S/N (signal to noise ratio). Rasio $\mathrm{S} / \mathrm{N}$ didapatkan dari pembagian konsentrasi rata-rata dan $\mathrm{SD}$

\section{HASIL DAN PEMBAHASAN}

\section{Working Range dan Linear Range}

Hasil pembacaan absorbansi deret standard konsentrasi rendah $(<5 \mathrm{mg} / \mathrm{L})$ dan deret standard konsentrasi tinggi ( $>5 \mathrm{mg} / \mathrm{L}$ ) adalah sebagai berikut :

TABEL II. HASIL PEMBACAAN ABSORBANSI DERET STANDARD KONSENTRASI $<5 \mathrm{mg} / \mathrm{L}$

\begin{tabular}{|c|c|}
\hline $\begin{array}{c}\text { Konsentrasi } \\
(\mathbf{m g} / \mathbf{L})\end{array}$ & Absorbansi \\
\hline 0 & -0.001 \\
\hline 0.502 & 0.011 \\
\hline 1.004 & 0.022 \\
\hline 2.008 & 0.044 \\
\hline 3.012 & 0.062 \\
\hline 4.016 & 0.079 \\
\hline 5.020 & 0.096 \\
\hline
\end{tabular}

Kemudian data tersebut diatas diplot dalam kurva kalibrasi, didapatkan persamaan sebagai berikut :

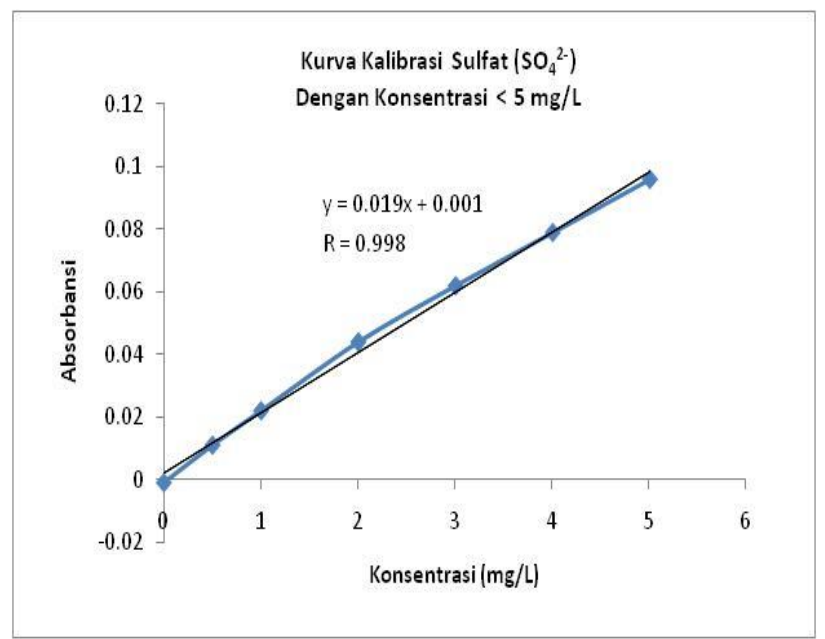

Gambar 1. Kurva Kalibrasi Sulfat Konsentrasi Rendah $(<5 \mathrm{mg} / \mathrm{L})$

Setelah itu dilakukan uji linearitas dengan membaca kembali absorbansi salah satu standard pada deret kurva kalibrasi dan menghitung kembali konsentrasi yang didapat dengan menggunakan persamaan linear kurva tersebut. Standard yang akan dibaca adalah $2.008 \mathrm{mg} / \mathrm{l}$, kemudian absorbansi yang didapat dimasukkan dalam persamaan $\mathrm{Y}=-0.019 \mathrm{X}-$ 0.001 .

TABEL III. UJI LINEARITAS KURVA KALIBRASI SULFAT

\begin{tabular}{|c|c|c|}
\hline Batas Keberterimaan & Hasil & Kesimpulan \\
\hline$R^{2}>0.990$ & 0.996 & DITERIMA \\
\hline $\begin{aligned} & \text { Intercept } \leq \text { MDLest } \\
& \text { MDLest }=(4 / 10)^{*} \text { LOQ } \\
& \text { MDLest }=(4 / 10)^{*} 1.9212 \\
& \text { MDLest }=0.7685\end{aligned}$ & $0.001 \leq 0.768$ & DITERIMA \\
\hline Laboratory Control Standard & & \multirow{3}{*}{ DITERIMA } \\
\hline $\begin{array}{l}\text { Kosent standard } 2.008 \mathrm{mg} / \mathrm{L} \\
\text { terbaca } 2.079 \mathrm{mg} / \mathrm{L}\end{array}$ & $\begin{array}{l}=2.079 / 2.008 * 100 \% \\
=95.394 \%\end{array}$ & \\
\hline$\% R_{L C S}=100 \% \pm 10 \%$ & $103.54 \%$ & \\
\hline
\end{tabular}

Gambar 1 dan Tabel 3 menunjukkan bahwa kurva kalibrasi tersebut sudah linear dan sesuai dengan standard pengendalian mutu sulfat yang tercantum pada SNI 6989.202009. Hasil uji linearitas menunjukkan hasil yang bisa diterima.

TABEL IV. HASIL PEMBACAAN ABSORBANSI DERET STANDARD KONSENTRASI $>5 \mathrm{mg} / \mathrm{L}$

\begin{tabular}{|c|c|}
\hline $\begin{array}{c}\text { Konsentrasi } \\
(\mathbf{m g} / \mathbf{L})\end{array}$ & Absorbansi \\
\hline 5.02 & 0.0560 \\
\hline 10.04 & 0.1135 \\
\hline 20.08 & 0.2035 \\
\hline 30.12 & 0.2965 \\
\hline 50.20 & 0.4580 \\
\hline
\end{tabular}




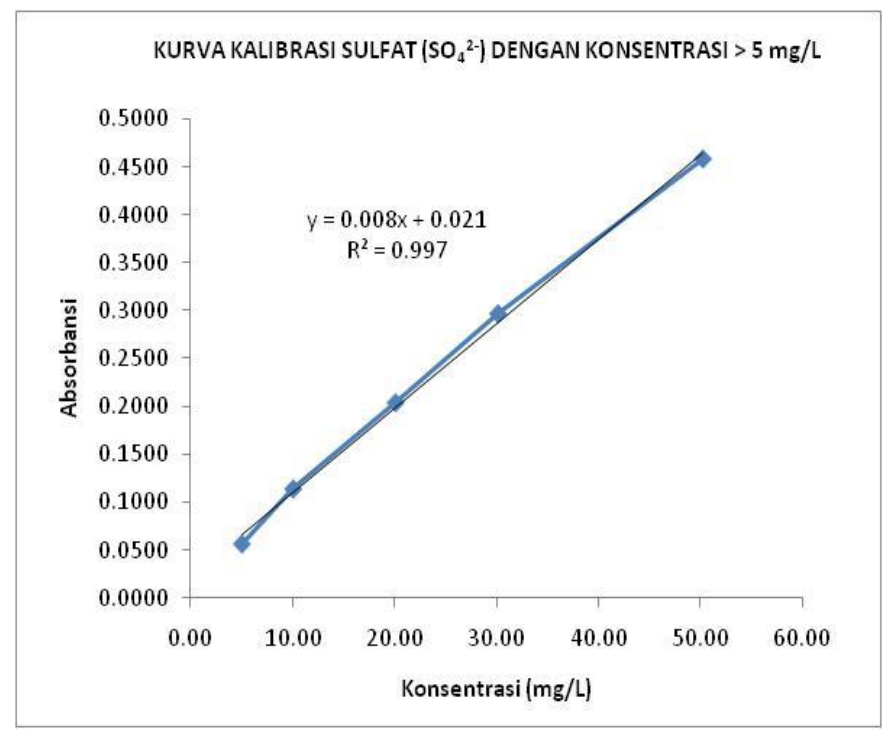

Gambar 2. Kurva Kalibrasi Sulfat Konsentrasi Rendah (> 5mg/L)

Gambar 2 menunjukkan kurva yang linear dan memenuhi persyaratan SNI 6989.20 : 2009. Ketika akan melakukan analisa, maka kita harus dapat memprediksi kisaran kadar sampel. Jika sampel $<5 \mathrm{mg} / \mathrm{L}$ maka persamaan kurva yang digunakan adalah Gambar 1, sedangkan jika kadar sulfat $>5$ $\mathrm{mg} / \mathrm{L}$, maka persamaan yang digunakan adalah Gambar 2 .

\section{Presisi (Repeatability dan Reproducibility)}

Sampel yang digunakan untuk uji presisi adalah air permukaan. Berikut ini adalah hasil pembacaan repeatability sampel :
TABEL V. HASIL PEMBACAAN PRESISI SUlFAt SAMPEL AIR PERMUKAAN

\begin{tabular}{|c|c|c|}
\hline No. & Konsentrasi $(X)$ & $(X-X r)^{\wedge} 2$ \\
\hline 1 & 10.125 & 0.140625 \\
\hline 2 & 10.688 & 0.03515625 \\
\hline 3 & 10.813 & 0.09765625 \\
\hline 4 & 10.938 & 0.19140625 \\
\hline 5 & 10.063 & 0.19140625 \\
\hline \multirow[t]{2}{*}{6} & 10.500 & 0 \\
\hline & 10.375 & 0.015625 \\
\hline Rata-2 (Xr) & & 10.500 \\
\hline$S D$ & & 0.335 \\
\hline CV (RSD) contoh & $\{\mathrm{SD} / \mathrm{Xr}\} * 100 \%$ & 3.187 \\
\hline $\mathrm{CV}_{\text {horwitz }}$ & $2^{\wedge}\left\{1-\left(0.5^{\star} \operatorname{LOG}\left(\mathrm{Xr}^{\star} 10^{\wedge}-6\right)\right)\right\}$ & 11.231 \\
\hline $\mathrm{CV}_{\text {repeatability }}$ & $1 / 2{ }^{*} \mathrm{CV}$ horwitz & 5.615 \\
\hline
\end{tabular}

\section{Batas Keberterimaan}

\begin{tabular}{|c|c|c|}
\hline \multirow{2}{*}{1} & $\mathrm{RSD}_{\text {contoh }}<\mathrm{CV}_{\text {Repeatability }}$ & \multirow{2}{*}{ DITERIMA } \\
\cline { 2 - 2 } & $3.187<5.615$ & \\
\hline
\end{tabular}

Tabel 5 menunjukkan hasil $\mathrm{RSD}_{\text {contoh }}<\mathrm{CV}$ Repeatability, yaitu $3,187<5.615$, sehingga dapat disimpulkan bahwa presisi sulfat memenuhi persyaratan batas keberterimaannya.

Sedangkan untuk kegiatan reproducibility, sampel dikerjakan oleh 2 orang analis yang berbeda dan didapatkan hasi sebagai berikut :

TABEL VI. HASIL REPRodUCibILITy ANALISA SUlFAT PADA AIR PERMUKAAN

\begin{tabular}{|c|c|c|c|c|}
\hline \multirow{2}{*}{ Ulangan } & \multicolumn{2}{|c|}{ Analis 1} & \multicolumn{2}{|c|}{ Analis 2} \\
\hline & Absorbansi & Konsentrasi (mg/L) & Absorbansi & Konsentrasi (mg/L) \\
\hline 1 & 0.1020 & 10.125 & 0.1030 & 10.250 \\
\hline 2 & 0.1065 & 10.688 & 0.1025 & 10.188 \\
\hline 3 & 0.1075 & 10.813 & 0.1045 & 10.438 \\
\hline 4 & 0.1085 & 10.938 & 0.1035 & 10.313 \\
\hline 5 & 0.1015 & 10.063 & 0.1065 & 10.688 \\
\hline 6 & 0.1050 & 10.500 & 0.1070 & 10.750 \\
\hline 7 & 0.1040 & 10.375 & 0.1055 & 10.563 \\
\hline Rata-rata & $=\sum$ konsentrasi $/ \mathrm{n}$ & 10.500 & $=\sum$ konsentrasi $/ \mathrm{n}$ & 10.455 \\
\hline Standard Deviasi (SD) & & 0.334632883 & & 0.21864368 \\
\hline$\%$ RSD & $=\mathrm{SD} / \mathrm{rata} 2 * 100 \%$ & 3.186979842 & $=\mathrm{SD} / \mathrm{rata} 2 * 100 \%$ & 2.091211985 \\
\hline CV horwitz & $=2 \mathrm{e}(1-0,5 \log \mathrm{C})$ & 11.23092889 & $=2 \mathrm{e}(1-0,5 \log C)$ & 11.23813370 \\
\hline 0.5 CV horwitz & $=0.5 *$ CV horwitz & 5.615464446 & $=0.5 *$ CV horwitz & 5.61906685 \\
\hline \multirow{2}{*}{$\begin{array}{l}\text { Syarat Keberterimaan } \\
\text { Repeatabilitas }\end{array}$} & $\%$ RSD $\leq 0.5$ CV horwitz & \multirow{2}{*}{ DITERIMA } & $\%$ RSD $\leq 0.5$ CV horwitz & \multirow{2}{*}{ DITERIMA } \\
\hline & $3.19<5.62$ & & $2.09<5.62$ & \\
\hline
\end{tabular}


Reprodusibilitas (14 Data)

\begin{tabular}{|l|l|r|}
\hline Rata-rata & $=\sum$ konsentrasi / n & 10.48 \\
\hline Standard Deviasi (SD) & & 0.27254933 \\
\hline$\%$ RSD & $=$ SD/rata2 * 100\% & 2.60123777 \\
\hline CV horwitz & $=2 \mathrm{e}(1-0,5 \log C)$ & 11.23452688 \\
\hline $\begin{array}{l}\text { O.67 CV horwitz } \\
\text { Syarat Keberterimaan } \\
\text { Reprodusibilitas }\end{array}$ & \% RSD $\leq \mathbf{0 . 6 7}$ CV horwitz & DITERIMA \\
\hline
\end{tabular}

Tabel 6 menunjukkan hasil yang memenuhi syarat keberterimaan, yaitu \%RSD $<0,67 \mathrm{CV}_{\text {horwitz. Sehingga dapat }}$ diartikan bahwa metode uji sulfat sesuai SNI 6989.20:2009 dapat diterapkan di laboratorium, karena meskipun diuji oleh dua analis yang berbeda dapat memberikan presisi yang cukup baik. Dimana kedua analis juga memenuhi syarat keberterimaan repeatability (presisi).

\section{Limit of Quantity (LOQ), Methods Detection Limit (MDL) dan Limit of Detection (LOD)}

Pembacaan 7 pengulangan sampel air permukaan yang mempunyai konsentrasi sangat kecil dengan penambahan spike $2 \mathrm{mg} / \mathrm{L}$ menunjukkan hasil sebagai berikut :

TABEL VII. HASIL PERHITUNGAN LOQ

\begin{tabular}{|c|c|c|c|}
\hline $\mathrm{n}$ & Absorbansi & $\begin{array}{c}\text { Konsentrasi contoh + } \\
\mathrm{sp}(\mathrm{mg} / \mathrm{L})\end{array}$ & Recovery (\%) \\
\hline 1 & 0.017 & 1.6471 & 82.35 \\
\hline 2 & 0.024 & 2.0588 & 102.94 \\
\hline 3 & 0.019 & 1.7647 & 88.24 \\
\hline 4 & 0.021 & 1.8824 & 94.12 \\
\hline 5 & 0.022 & 1.9412 & 97.06 \\
\hline 6 & 0.018 & 1.7059 & 85.29 \\
\hline 7 & 0.026 & 2.1765 & 108.82 \\
\hline \multicolumn{2}{|c|}{ Rata-rata konsentrasi } & $=\sum$ konsentrasi $/ \mathrm{n}$ & 1.8824 \\
\hline \multicolumn{2}{|l|}{ SD } & & 0.1921 \\
\hline \multirow{2}{*}{\multicolumn{2}{|c|}{ MDL }} & $=$ nilai tabel $\mathrm{t}$ *SD & 06028 \\
\hline & & $=3.143 * \mathrm{SD}$ & \\
\hline \multicolumn{2}{|l|}{ LOQ } & $=10 * S D$ & 1.9212 \\
\hline \multicolumn{2}{|l|}{ LOD } & $=3 * S D$ & 0.5764 \\
\hline \multicolumn{2}{|c|}{ Spike (mg/L) } & & 2.0 \\
\hline \multicolumn{2}{|c|}{ Rata-rata \% Spike } & $=\sum \%$ Recovery $/ \mathrm{n}$ & 94.12 \\
\hline \multicolumn{2}{|c|}{ S/N Estimate } & $=$ Rata $2 / S D$ & 9.80 \\
\hline
\end{tabular}

\section{Batas Keberterinaan}

\begin{tabular}{|c|l|r|r|}
\hline 1 & MDL $<$ baku mutu & $0.604<250$ & DIIERIMA \\
\hline 2 & High Spike Check $=\mathrm{sp}<10^{*} \mathrm{MDL}$ & $2 \mathrm{mg} / \mathrm{L}<6.038$ & DIIERIMA \\
\hline 3 & Low Spike Check $=\mathrm{sp}>\mathrm{MDL}$ & $2 \mathrm{mg} / \mathrm{L}>0.604$ & DIIERIMA \\
\hline 4 & S/N Estimate $=2.5<\mathrm{S} / \mathrm{N}<10$ & 9.80 & DIIERIMA \\
\hline 5 & Ratarata \% Recowery $=85<$ ave $\mathrm{R}<115$ & 94.12 & DIIERIMA \\
\hline
\end{tabular}

Tabel 7 menunjukkan bahwa hasil perhitungan LOQ telah memenuhi syarat keberterimaan. Dimana LOQ pengujian sulfat dengan menggunakan metode SNI 6989.20 : 2009 adalah $1.92 \mathrm{mg} / \mathrm{L}$, sedangkan MDL nya adalah 0.604 $\mathrm{mg} / \mathrm{L}$. Jika LOQ yang didapatkan lebih besar dari baku mutu sampel, maka yang dituliskan di lembar hasil uji adalah nilai MDL nya. Persyaratan kadar sulfat maksimum dalam baku mutu air bersih yang mengacu pada PERMENKES 416 tahun 1990 adalah $250 \mathrm{mg} / \mathrm{L}$. Sedangkan LOQ yang didapatkan adalah $1.92 \mathrm{mg} / \mathrm{L}$, dengan demikian maka nilai LOQ masih bisa dicantumkan dalam lembar hasil uji.

\section{Akurasi (Recovery)}

Akurasi merupakan salah satu kegiatan verifikasi metode dan pengendalian mutu. Akurasi dilakukan dengan menambahkan spike pada sampel. Dan didapatkan hasil sebagai berikut :

TABEL VIII. HASIL PERHITUNGAN AKURASI

\begin{tabular}{|l|c|c|}
\hline & Absorbansi & Konsentrasi \\
\hline Sampel & 0.256 & $29.375 \mathrm{mg} / \mathrm{L}$ \\
\hline Spike & - & $5 \mathrm{mg} / \mathrm{L}$ \\
\hline Sampel + sp & 0.298 & 34.625 \\
\hline \% Recovery & $\frac{34.625-29.375}{5} \times 100=105 \%$ \\
\hline keberterimaan & \multicolumn{2}{|c|}{$90 \%<\%<110 \%$} \\
\hline Kesimpulan & \multicolumn{2}{|c|}{ Akurasi Diterima } \\
\hline
\end{tabular}

\section{KESIMPULAN}

Dari kegiatan verifikasi dan validasi metode uji sulfat ini, didapatkan nilai $\mathrm{LOQ}=1.9212$, $\mathrm{LOD}=0.5764$ dan $\mathrm{MDL}=0.6038$. Sedangkan uji presisi dan reproducibility didapatkan hasil yang memenuhi syarat keberterimaan. RSD uji presisi yang didapatkan adalah 3,187 lebih kecil dari 0.5 CV horwitz, yaitu 5.615. sedangkan uji reproducibility didapatkan RSD 2.601 lebih kecil dari 2/3 CV horwitz, yaitu 7.527. Kurva kalibrasi yang dibuat mempunyai linearitas ( $r$ ) $=0.997$ untuk konsentrasi sulfat $>5 \mathrm{mg} / \mathrm{L}$, sedangkan untuk konsentrasi sulfat $<5 \mathrm{mg} / \mathrm{L}$ didapatkan $\mathrm{r}$ kurva kalibrasi $=0.998$. \% Recovery dari uji akurasi didapatkan nilai $105 \%$, masih berada dalam range keberterimaan.

Verifikasi metode uji sulfat dalam air dan air limbah secara turbidimetri sesuai SNI 6989.20: 2009 telah memenuhi syarat keberterimaan, sehingga metode ini dapat diterapkan di laboratorium uji lingkungan Baristand Industri Surabaya.

\section{UCAPAN TERIMA KASIH}

Ucapan terima kasih ditujukan kepada Ibu Frida Sustyawati dan Ibu Moeljaningsih dan semua pihak yang telah membantu terlaksananya verifikasi metode uji sulfat sesuai SNI 6989.20: 2009.

\section{DAFTAR PUSTAKA}

[1] William horwitz, Offical Methods of Analysis of AOAC International, edisi 17, Association of Official Analytical Chemists, Michigan, 2000

[2] Harmita, 2004, Petunjuk Pelaksanaan validasi metoda dan cara perhitungannya, Majalah Ilmu kefarmasian Vol 1, hal 119 - 122 
[3] Badan Standardisasi Nasional (BSN), Jakarta, SNI 6989.20 : 2009, Air dan Air Limbah-Bagian 20 : Cara uji sulfat (SO42-) secara turbidimetri

[4] Harvey D, Modern Analitycal Chemistry, Mc Graw Hill Companies, USA, 2000, Hal. 36 - 42

[5] B. Magnusson and U. Ornemark (eds) Eurachem Guide, The FitnessFor Purpose of Analytical Methods, A Laboratory Guide to Methods Validation, and Related Topics, second edition, 2014, halaman 16 - 36

[6] Steven K. Thompson, On Sampling and Experiments, environmetrics, 2002, pp 67-71, 89-92 